\title{
CLIENT SATISFACTION AFTER FAMILY PLANNING COUNSELING BY TRAINED MEDICAL STUDENTS
}

\author{
Shinta Prawitasari ${ }^{1}$, Diannisa I E Sangun ${ }^{2}$, M Nurhadi Rahman ${ }^{3}$, Ova Emilia $^{4}$
}

\begin{abstract}
ABSTRAK
Latar Belakang: Program keluarga berencana mengalami tren penurunan di Indonesia dikarenakan adanya kendala pengetahuan, hambatan budaya, dan ketidakpuasan klien terhadap efek dari penggunaan alat kontrasepsi. Konseling keluarga berencana oleh penyedia layanan kesehatan memainkan peran yang penting dalam memberikan informasi mengenai metode program keluarga berencana.

Tujuan: Mengetahui kepuasan klien terhadap konseling keluarga berencana yang dilakukan oleh mahasiswa kedokteran yang telah dilatih.

Metode: Penelitian ini merupakan pre-experiment design with posttest only. Dua puluh lima mahasiswa kedokteran yang mengikuti progam ditugaskan untuk memberikan konseling keluarga berencana kepada klien program keluarga berencana di Kabupaten Sleman, Yogyakarta. Modifikasi kuisioner dari William dkk digunakan untuk menilai kepuasan klien. Analisis deskriptif dilakukan dengan program SPSS versi 21.

Hasil dan Pembahasan: Dari 69 klien yang mendapatkan pelayanan,secara umum lebih dari $97 \%$ klien merasa puas dengan pelayanan yang diberikan kecuali pada poin waktu tunggu dimana ketidakpuasan klien $11,8 \%$. Kepuasan pada poin merasa dihormati, durasi konseling, metode pemberian informasi, kesempatan bertanya, dan kesesuaian antara informasi yang dibutuhkan dengan yang diberikan mencapai 98,5-100\%.
\end{abstract}

Kesimpulan: Sebagian besar klien merasa puas dengan konseling yang diberikan oleh mahasiswa kedokteran.

Kata kunci: kepuasan, keluarga berencana, konseling, mahasiswa kedokteran

\section{ABSTRACT}

Background: Family planning programs experiencea declining trend in Indonesia due to knowledge constraints, cultural barriers, and client dissatisfactions toward the effects of using contraceptive method. A family planning counselling by a health provider would play pivotal role in informing the correct information regarding the side effects of family planning methods.

Objective: To determine the client's satisfactions toward family planning counseling by trained medical students.

Method: This study was pre-experiment design with posttest only. Twenty five medical students in the program were assigned to conduct family planning counseling towards family planning clients in Sleman District, Yogyakarta. Questionnaire modification from William et al was used to assess client satisfaction. Descriptive analysis were done by SPSS 21 software .

Result and Discussion: Of the 69 clients who received service, in general more than $97 \%$ of clients were satisfied with the services provided, except on the waiting time points where client dissatisfaction reached

1,2,3,4 Departemen Obstetri dan Ginekologi, Fakultas Kedokteran Universitas Gadjah Mada 
11.8\%. Satisfaction on the points being respected, duration of counseling, methods of giving information, opportunity to ask, and the suitability between the required information to the given reached $98.5-100 \%$.

Conclusion: Most clients were satisfied with the counseling provided by medical students.

Keywords: satisfaction, family planning, counseling, medical student

\section{INTRODUCTION}

Family planning program is still a challenge in Indonesia. Contraceptive prevalence rate in Indonesia is around 61.9\% in 2012 based on Indonesia's Demographic Health Survey. There is declining trend toward the use of long term method such as intrauterine device and implant. Many factors contribut to this, ranging from knowledge constraints, cultural myths, and client dissatisfactions.

A client may feeldissatisfied due to side effects of the family planning method she use. A family planning counselling by a health provider would play pivotal role in informing the correct information regarding side effects of family planning methods.

Indonesian physician competency standard released in 2012 includes family planning practices such as family planning counselling as level 4 for competency standard, as well as intrauterine device (IUD) and implant insertion and withdrawal. ${ }^{1}$

Obstetrics and Gynecology Department, Faculty of Medicine, Universitas Gadjah Mada has a unique elective program for undergraduate medical student at year 4 , to introduce family planning practices. The program consists of family planning introduction and skill practices in performing family planning counselling, IUD and implant insertion and withdrawal. Every year, during $2^{\text {nd }}$ semester, 60 medical students joint this 3 weeks program. The students practice to do family planning counselling, IUD and implant insertion in real patients at the end of the program under direct and close supervision of the Obstetrics and Gynecology staffs.

Patient satisfaction is proved beneficial for providing a direct indicator for quality of care in family planning service including family planning counselling. ${ }^{2}$ To measure the quality of family planning counselling done by trained medical students, we measured the client satisfaction.

\section{METHOD}

This study was pre-experiment design with posttest only. Twenty five fourth year medical students were participating in this program. After they were trained, they were assigned to perform counseling of all contraceptive methods for 69 clients in Sleman District, Yogyakarta Indonesia.

We used exit interview's questionnaires modified from Williams et $\mathrm{al}^{3}$ to measure the client satisfaction since it proves to be easy, inexpensive, useful to assess many aspect of quality of care, easy to apply and client oriented.

The questionnaires consist of accessibility, cleanliness, cost, the conformity between cost and counselling service, waiting time, privacy, feeling respected, the duration of counselling, the methods of family planning information given, the opportunity to ask to the provider, and the between the need and the information given. Descriptive analysis of the questionaire were conducted using Statistical Package for the Social Sciences (SPSS) version 21. 


\section{RESULT AND DISCUSSION}

We viewed client satisfcation as a key outcome of good quality of care that can be an important factor to achieve family planning program sustainability.

We defined dissatisfaction as any item in the questionnaire where at least $5 \%$ of respondents expressed dissatisfaction based on Williams et al.'s study. They chose the level of 5\% due to the belief that a low threshold should be used to detect areas of improvement. When the model questionnaire was pretested, the 5\%'s threshold proved to be satisfied to detect areas need for improvement ${ }^{3}$.

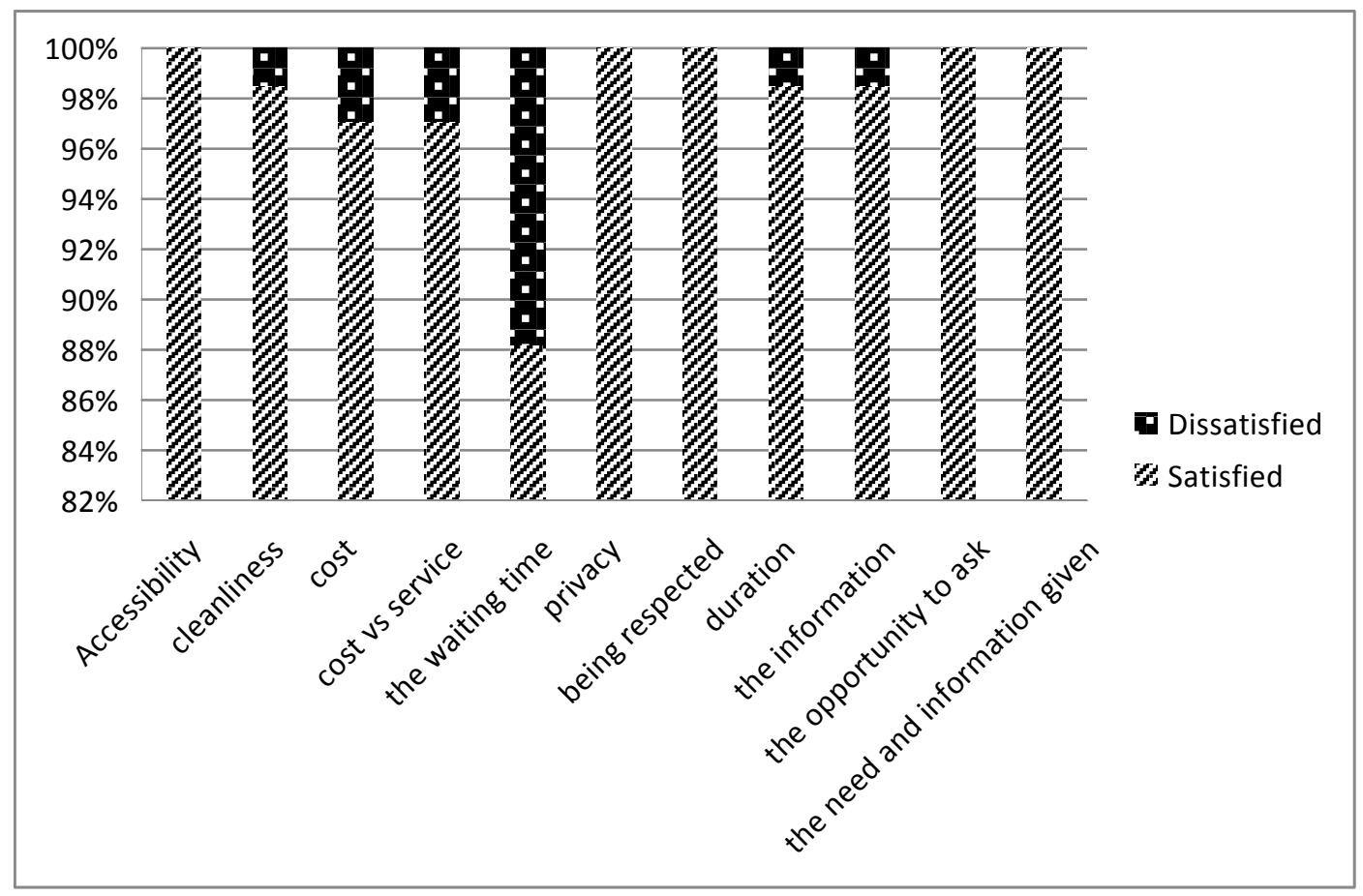

Figure 1. client's satisfaction according to william et al.'s quesionnaire

In general, more than $97 \%$ clients were highly satisfied with the service they received ie. location and counselling service. Despite the high reported levels of satisfaction, several clients were express their dissatisfaction. Of the 11 questions asked, the only item clients declared to be dissatisfied was long waiting time (11.8\%).

Williams et al. stated that the clients may be easier to state dissatisfaction upon the less personal aspect such as waiting times and harder to make negative remark with interactions with providers. It is showed in our study that the clients expressed highest satisfaction on privacy, being respected, the duration of counselling, the information of family planning methods given, the opportunity to ask to the provider, and the conformity between the need and the information given. ${ }^{3}$

Koaje et $\mathrm{al}^{4}$ found that the predictors for client satisfaction were clinic waiting time, providers, and other clinic staffs behavior toward the clients, particularly respect and politeness, being examined during the visit and sanitary condition. They found that the most powerful 
predictor was waiting time, which showed that clients who waited for an average of $35 \mathrm{~min}$ were 8 times more likely to be satisfied. Their finding for waiting time was concurrence with our finding.

The fact that the family planning counselling were done by the trained medical students showed that the clients considered the medical students as a medical provider who were competent in doing the counselling. It is showed in the study result, where the satisfactions in questionnaires items such as being respected, the duration of counselling, the information of family planning methods given, the opportunity to ask to the provider, and the conformity between the need and the information given reach $98.5 \%$ $100 \%$.

Nonetheless, satisfaction in client's perspective had no relation with satisfaction towards the competency of the provider in delivering the correct and sufficient information about family planning methods and the clinical skills of the provider. The clients in the developing country didn't have enough knowledge to measure the appropriate family planning services standard procedures. ${ }^{4}$

Client satisfaction exit interviews should be considered as one tool to quality assess in family planning service. They should be used together with other quality measurement such as direct observation, provider surveys, site inventories, reviews of client records or focus groups. Quality is a broad concept that should be measured with various measurements and hence client exit interviews was able to measure many aspects of family planning and reproductive health services. They may provide us with understanding of how clients perceive certain subjective aspects of quality of care and access to services that may be difficult to assess with other evaluation methodologies. The modest way to ask client's views, and to make the service provider to listen to them, regarded as the most important outcome from using this methodology. ${ }^{3}$

To overcome the long waiting time which may discourage them to seek family planning service, we could provide them with interesting leaflet on various family planning methods or arrange the attendance of client to avoid long waiting times.

\section{CONCLUSION}

The vast majority of clients were satisfied with counseling provided by medical students. The dissatisfaction in waiting time to be served gave an insight and space for improvement in our family planning service. Nevertheless counseling should be strengthened in order to bridge the knowledge gap, achieve understanding and increase compliance. By giving appropriate counseling and optimal family planning service, it is expected that the contraceptive rate will be higher and more sustainable.

\section{REFERENCES}

1. Indonesian Medical Council, Indonesian physician competency standard, 2012

2. Nasr EH, Hassan HE. 2016. "Association between quality of family planning services and client's satisfaction level in maternal and child health centers in Port Said city". Journal of Nursing Education and Practice. 6(1): 85-99.

3. Williams T, Schutt-Ainé J, and Cuca Y. 2000. "Measuring family planning service quality through client satisfaction exit interviews". International family planning perspectives. 26(2):63-71.

4. Kaoje UA, Sambo MN, Oche MO, Saad A, Raji MO and Isah BA. 2015. "Determinants of client satisfaction with family planning services in government health facilities in Sokoto". Northern Nigeria Sahel medical Journal. 18(1): 20-26. 